\title{
ゲーム依存とアンヘドニア傾向の関連 一一行動活性化による介入可能性の検討
}

\author{
古 賀 佳 樹 \\ 中京大学大学院心理学研究科
}

山本竜也

名古屋市立大学大学院人間文化研究科

\section{川島大 輔}

中京大学心理学部

\section{問題と目的}

近年ゲーム依存やゲーム障害とよばれるゲームの過剩使 用に関連した問題が注目されてきている。WHOが2019年 に「ゲーム障害 (Gaming Disorder)」を国際疾患として ICD-11に正式認定するなど，ゲームの問題を病理として扱 う動きもある。先行研究でも, ゲーム依存・障害への介入 のため, 様々な関連要因の検討がなされてきた。その中で も, 抑うつはゲーム依存との強い関連性があると示唆され ている (e.g., Brunborg, Mentzoni, \& Fr $\phi$ yland, 2014)。さら に近年, うつの中核症状であるアンヘドニア傾向（快感消 失) がゲーム依存に影響する可能性も報告されている (Guillot et al., 2016)。加えて Guillot et al. (2016) は, （ゲー ム依存者も含まれる) ネット依存治療 (Wölfling, Beutel, Dreier, \& Müller, 2014）に行動活性化療法を加えた介入方 法の可能性についても理論的見地から言及している。ここ から，アンヘドニア傾向がゲーム依存に影響すること，行 動活性化がその影響過程に作用する可能性がうかがえる。 しかし Guillot et al. (2016) の報告以外にゲーム依存とアン ヘドニア傾向の関係について検討したものは管見では見当 たらず，結果の再現性が十分確認されていない。またこの 研究では「過去30日の間あなたはゲームに依存していたと 思いますか?」の単項目を用いて「はい，いいえ」の2 件 法で回答を求めており, 測定上の問題がある。さらに行動 活性化との関連について, Guillotらはあくまで理論的な示 唆を呈しているのみであり, 実証的な検討はなされていな w。

そこで本研究では, ゲーム依存とアンヘドニア傾向, 行 動活性化の相関関係を確認したうえで，アンヘドニア傾向 がゲーム依存にどのような影響を及ぼすのか，また行動活 性化がその影響プロセスにどのように作用するのかを実証 的に検討することを目的とする。特に後者については，調 整分析と媒介分析, すなわちアンへドニア傾向からゲーム 依存への影響を行動活性化が調整するモデルと, 行動活性 化とゲーム依存の直接効果とアンヘドニア傾向を媒介とし た間接効果を想定したモデルを構成し，探索的に検討する。

\section{方 法}

調査方法と対象者 2019年 5 月にモニターサイト フ リージーを介して, Webによる質問紙調査を実施した。フ リージーの保持する 18 から 65 歳の男女 800 名から調査への 同意とともに回答を回収した。得られたデータのうち, ダ ミ一項目拉よび後述するシリアスネス・チェックへの回答 から，質問に誠実に答えていないと判断した262名を除外 した。残った 538 名 (有効回答率 $67 \%$ ) のうち, 最終的に ゲーム使用者 248 名のデー夕 (男 145 名, 女 103 名; $M_{\text {age }}=$ $45.76, S D_{\text {age }}=11.32$ )を分析に用いた。なおデー夕分析には, IBM SPSS Statistics 23 抢よびHAD（清水，2016）を使用し た。

質問紙 ゲーム依存度の測定には古賀・川島 (2018)の 日本語版 Game Addiction Scale (GAS7-J ${ }^{1)}$ ) を用いた (5 件 法, 7 項目, $M=1.34, S D=0.54, \alpha=.97)$ 。アンヘドニア傾 向の測定にはNagayama et al. (2012)の日本語版SnaithHamilton Pleasure Scale (SHAPS- ${ }^{2,3}$; 4件法, 14項目, $M=0.21, S D=0.24, \alpha=.88$ ）を用いた。行動活性化は, 山 本 ·首藤 ·坂井 (2015) の日本語版 Behavioral Activation for Depression Scale-Short Form (BADS-SF; 7 件法, 8項目, $M=3.16, S D=1.03, \alpha=.82 ）$ を用いた。そのほか, 質問紙 には抑うつ4）と属性変数として性別，年齢に関する質問が 含まれていた。なお, 本調査では不誠実回答の除去手続き としてダミー項目と, 不真面目な回答の検出力の高いとさ れる Aust, Diedenhofen, Ullrich, \& Musch (2013)のシリア

1）GAS7-Jで測定されるゲーム依存は診断名としてのゲーム障 害と一致しているわけではないが, ICD-11やDSM-5の診 断基準をお打むね反映している。

2）SHAPSは名称上では快感情を測定する尺度であるが, アン ヘドニア傾向を測定する尺度として妥当性・信頼性の報告 がされている (Nagayama et al., 2012)。

3) Nagayama et al. (2012) に従い，4件法の 1,2を0 点，3,4を 1 点として得点を算出した。

4）本研究では抑うつ傾向も測定していたが, アンへドニア傾 向を包括する概念であるため本文分析からは除外した。な お確認のため, 抑うつ傾向についても相関分析, 調整・媒 介分析を行ったところ，いずれにおいてもアンへドニア傾 向と同様の結果を示した。 


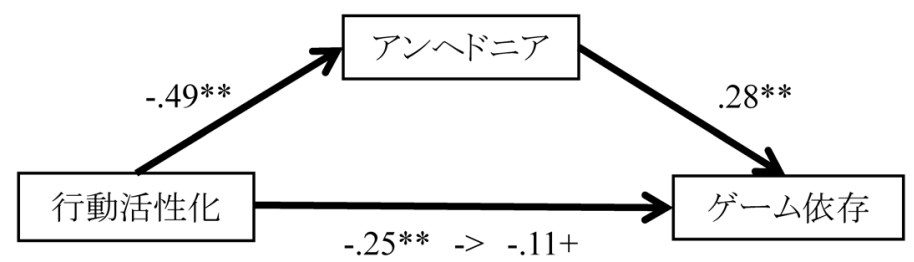

注. 図中の係数は標準化係数を示す。

** $p<.01,{ }^{\dagger} p<.10$

Figure 1 アンヘドニア傾向を媒介変数とした媒介分析の結果

スネス・チェックを用いた。

\section{結 果}

以下の分析に先立って使用変数の分布を確認したところ, ゲーム依存とアンヘドニア傾向はサンプルが最小值へ大き く偏っていたため, これらの2変数については対数変換を 行ったうえで以降の分析に用いた。ゲーム依存, アンへド ニア傾向，抑うつの関連を検討するために，Pearsonの相 関係数を算出した結果，すべての変数間に有意な相関関係 が認められた（ゲーム依存-アンへドニア傾向： $r=.33$, $p<.001$, ゲーム依存-行動活性化 : $r=-.25, p<.001$, アンへ ドニア傾向-行動活性化 : $r=-.49, p<.001)$ 。

アンヘドニア傾向がゲーム依存に及ぼす影響について, 行動活性化を調整変数とした一般化線形モデリングによる 調整分析を行った結果, ゲーム依存に対するアンへドニア 傾向の有意な正の主効果が認められ $(\beta=.265, p<.001)$, 行動活性化の主効果 $(\beta=-.116, p=.052)$ 拉よびアンへド ニア傾向と行動活性化の交互作用効果は有意ではなかった $(\beta=-.073, p=.242)$ 。次に, アンヘドニア傾向を媒介変数 とした一般化線形モデリングによる媒介分析を行った結果 (Figure 1), 行動活性化からゲーム依存への直接効果は, 媒 介変数の投入前は有意な負の係数を示していたが，媒介変 数の投入後は有意な係数を示さなかった。間接効果につい ては，行動活性化からアンヘドニア傾向へ有意な負のパス 係数が示され，アンヘドニア傾向からゲーム依存へ有意な 正のパス係数が示された。間接効果を検討するため, Sobel 検定を実施したところ有意な值が確認された $(z=-3.503$, $b=-.136, p<.001$ )。またブートストラップ法（ブートスト ラップ標本数 10000）を用いた有意性の検定も行ったとこ ろ, 有意な間接効果が確認された $(95 \% \mathrm{CI}$ : [-0.008, $-0.003]$ )。

\section{考察}

本研究では, ゲーム依存とアンヘドニア傾向, 行動活性 化の関連を検討した。相関分析の結果, 先行研究 (Guillot et al., 2016）と同様，ゲーム依存，アンヘドニア傾向，そし て行動活性化の間に有意な相関関係が認められた。また調 整分析を実施した結果，行動活性化の調整効果は有意な值 を示さなかった。媒介分析では，最終モデルにおいて行動 活性化からゲーム依存への直接効果が有意ではなかった一
方で，アンヘドニア傾向を媒介した間接効果が確認された。 この結果から，行動活性化はゲーム依存に直接影響するの ではなく，アンヘドニア傾向を媒介してゲーム依存に影響 すること, すなわち行動活性化療法がアンヘドニア傾向を 抑制することでゲーム依存を抑制する可能性が示された。 これはGuillot et al. (2016) による理論的見解を支持する実 証的知見といえる。

しかし本調査は横断研究であり, 行動活性化とアンへド ニア傾向，ゲーム依存の因果関係を結論づけることには慎 重にならなければならない。また, 調整・媒介分析に関し ては, 実証的な先行研究がなく探索的な分析にとどまって いる点にも十分留意しなければならない。今後, 縦断研究 や介入研究を通じて本研究で得られた知見について再度検 討することが必要であろう。

\section{引用文献}

Aust, F., Diedenhofen, B., Ullrich, S., \& Musch, J. (2013). Seriousness checks are useful to improve data validity in online research. Behavior Research Methods, 45, 527-535.

Brunborg, G. S., Mentzoni, R. A., \& Frøyland, L. R. (2014). Is video gaming, or video game addiction, associated with depression, academic achievement, heavy episodic drinking, or conduct problems? Journal of Behavioral Addictions, 3, 27-32.

Guillot, C. R., Bello, M. S., Tsai, J. Y., Huh, J., Leventhal, A. M., \& Sussman, S. (2016). Longitudinal associations between anhedonia and internet-related addictive behaviors in emerging adults. Computers in Human Behavior, 62, 475-479.

古賀佳樹 · 川島大輔 (2018). 日本語版 Game Addiction Scale (GAS7-J) の作成と妥当性の検討 パーソナリティ 研究, 27, 175-177.

Nagayama, H., Kubo, S. I., Hatano, T., Hamada, S., Maeda, T., Hasegawa, T., ... Baba, Y. (2012). Validity and reliability assessment of a Japanese version of the Snaith-Hamilton pleasure scale. Internal Medicine, 51, 865-869.

清水裕士 (2016).フリーの統計分析ソフト HAD——機能の 紹介と統計学習・教育, 研究実践における利用方法の提 案——メディア・情報・コミュニケーション研究, 1 , 59-73. 
Wölfling, K., Beutel, M. E., Dreier, M., \& Müller, K. W. (2014). Treatment outcomes in patients with internet addiction: A clinical pilot study on the effects of a cognitive-behavioral therapy program. BioMed Research International, 2014. https://doi.org/10.1155/2014/425924
山本竜也 · 首藤祐介 · 坂井 誠 (2015). Behavioral Activation for Depression Scale-Short Form (BADS-SF) 日本語版の 作成と信頼性 - 妥当性の検討 認知療法研究, 8, 96-105. -2019.11.14受稿, 2020.4.5 採択一

\title{
The Relationship between Game Addiction and Anhedonia: Exploring the Possibility of Intervention by Behavioral Activation
}

\author{
Yoshiki KogA $^{1}$, Tatsuya Yamamoto ${ }^{2}$ and Daisuke Kawashima ${ }^{3}$ \\ ${ }^{1}$ Graduate School of Psychology, Chukyo University \\ ${ }^{2}$ Graduate School of Humanities and Social Sciences, Nagoya City University \\ ${ }^{3}$ School of Psychology, Chukyo University
}

The Japanese Journal of Personality 2020, Vol. 29 No. 1, 31-33

This study aimed to examine the effects of anhedonia and behavioral activation on game addiction. A sample of 248 game players completed a questionnaire that collected information regarding game addiction, anhedonia, and behavioral activation. The results of the causal mediation analysis showed that behavioral activation did not directly affect game addiction but, instead, had an indirect effect: anhedonia mediated the relationship between behavioral activation and game addiction. This finding suggests that behavioral activation could be one of the effective intervention strategies for compulsive game players with anhedonia.

Key words: game addiction, anhedonia, behavioral activation 